Article

\title{
Carbazole- and Triphenylamine-Substituted Pyrimidines: Synthesis and Photophysical Properties
}

\author{
Sylvain Achelle ${ }^{1, *(\mathbb{D}}$, Julián Rodríguez-López ${ }^{2, *} \mathbb{0}$, Massinissa Larbani ${ }^{1}$, \\ Rodrigo Plaza-Pedroche ${ }^{2}$ and Françoise Robin-le Guen ${ }^{1}$ \\ 1 Université de Rennes, CNRS, Institut des Sciences Chimiques de Rennes-UMR 6226, F 35000 Rennes, France; \\ massilarb06@gmail.com (M.L.); francoise.le-guen@univ-rennes1.fr (F.R.-l.G.) \\ 2 Área de Química Orgánica, Facultad de Ciencias y Tecnologías Químicas, Universidad de \\ Castilla-La-Mancha, Avda. Camillo José Cela 10, 13071 Ciudad Real, Spain; rodripedroche@gmail.com \\ * Correspondence: sylvain.achelle@univ-rennes1.fr (S.A.); julian.rodriguez@uclm.es (J.R.-L.); \\ Tel.: +33-296-469-448 (S.A.); +34-926-295-300 (J.R.-L.)
}

Academic Editor: Frédéric Paul

Received: 11 April 2019; Accepted: 3 May 2019; Published: 5 May 2019

check for updates

\begin{abstract}
A series of pyrimidine derivatives bearing one, two or three triphenylamine/9-ethylcarbazole substituents has been synthesized by Suzuki cross-coupling reaction. All compounds showed absorption bands in the UV region and the emission of violet-blue light upon irradiation. Protonation led to quenching of the fluorescence, although some derivatives remained luminescent with the appearance of a new red-shifted band in the spectra. Accurate control of the amount of acid enabled white photoluminescence to be obtained both in solution and in solid state.
\end{abstract}

Keywords: pyrimidines; fluorescence; white-light emission; intramolecular charge transfer

\section{Introduction}

The pyrimidine (1,3-diazine) core is a $\pi$-deficient six-membered heterocycle with two nitrogen atoms. Consequently, the pyrimidin-4-yl and the pyrimidin-2-yl fragments act as relatively strong electron-withdrawing groups [1]. With regard to pyridyl analogues, the presence of an appropriately positioned second nitrogen atom significantly enhances their electron-attracting character [2]. The pyrimidine ring has therefore been extensively used as an acceptor unit in push-pull structures in which significant intramolecular charge transfer (ICT) occurs [1,3,4]. In this respect, 4,6-di(arylvinyl)pyrimidines are now well established two-photon absorption chromophores for biological imaging [5-8], 3D lithographic microfabrication [9], and 3D data storage [10]. Appropriately substituted 2,4,6-triarylpyrimidines have also been developed as efficient emitters for OLEDs due to their thermally activated delayed fluorescence (TADF) properties [11-15]. Pyrimidine push-pull chromophores have also been developed as second order nonlinear optic (NLO) materials $[16,17]$ and as dyes for photovoltaic applications [18,19].

When compared to their arylvinyl- and arylethynyl- analogues, arylpyrimidines generally exhibit a blue-shifted emission with a higher emission quantum yield [1,20]. Arylpyrimidines can be easily obtained by Suzuki cross-coupling reaction from halogenopyrimidines [21-24]. The electron-withdrawing character of the pyrimidinyl fragments allows this reaction to be performed from chloro-derivatives [25].

The emission properties of pyrimidine fluorophores are highly sensitive to the environment. As a consequence, a strong emission solvatochromism, which is typical of ICT chromophores [26-29], is observed: a polarity increase provides a significant bathochromic shift of the emission band [30-33]. On the other hand, protonation of the pyrimidine ring $\left(\mathrm{pK}_{\mathrm{a} 1}=1.1\right)$ significantly enhances its electron-withdrawing character and leads to a red-shift of both absorption and emission bands. These shifts are generally accompanied by emission quenching, but in some cases, particularly with weak electron-donating groups 
such as methoxy fragments, red-shifted emission with increased intensity is observed [32,34,35]. White photoluminescence can be obtained both in solution and in doped polystyrene films when the neutral and protonated forms are present in the appropriate ratio [34,35].

Triphenylamine and 9-ethylcarbazole have been extensively used as electron-donating units in push-pull structures [36-39]. Although these units are weaker electron-donors than $N, N$ dialkylanilines [40], derivatives that incorporate these moieties generally have stronger luminescence properties [41-43]. Nevertheless, only a few pyrimidine derivatives bearing triphenylamine or 9-ethylcarbazole fragments have been described in the literature $[9,19,44,45]$.

We report here the synthesis of a series of pyrimidine chromophores with one, two or three triphenylamine/9-ethylcarbazole substituents. The photophysical properties of the new materials were carefully studied and the luminescence behaviour in the presence of acid was evaluated. In some cases, the protonated pyrimidines remained emissive, which enabled white luminescence to be obtained by accurate control of the amount of acid.

\section{Results and Discussion}

\subsection{Synthesis}

Compounds 1 and $\mathbf{2}$ were obtained in moderate to good yield by Suzuki cross-coupling reaction from the corresponding chloropyrimidines and boronic acids according to a known methodology for similar pyrimidine structures (Scheme 1) [21-24]. All compounds were identified by ${ }^{1} \mathrm{H}$ and ${ }^{13} \mathrm{C}-\mathrm{NMR}$, and all previously unknown molecules were also characterized by high resolution mass spectroscopy (HRMS).

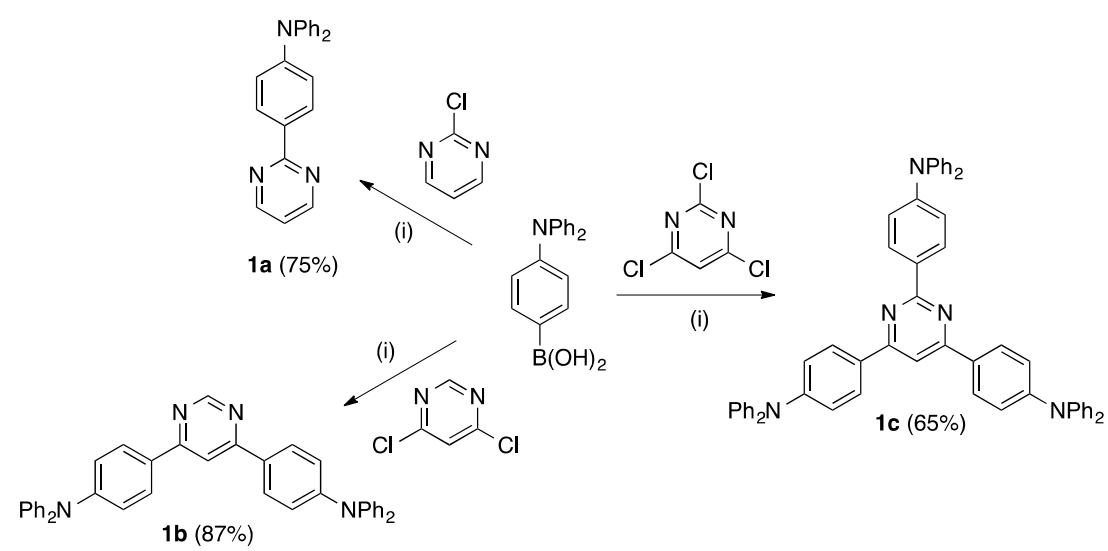

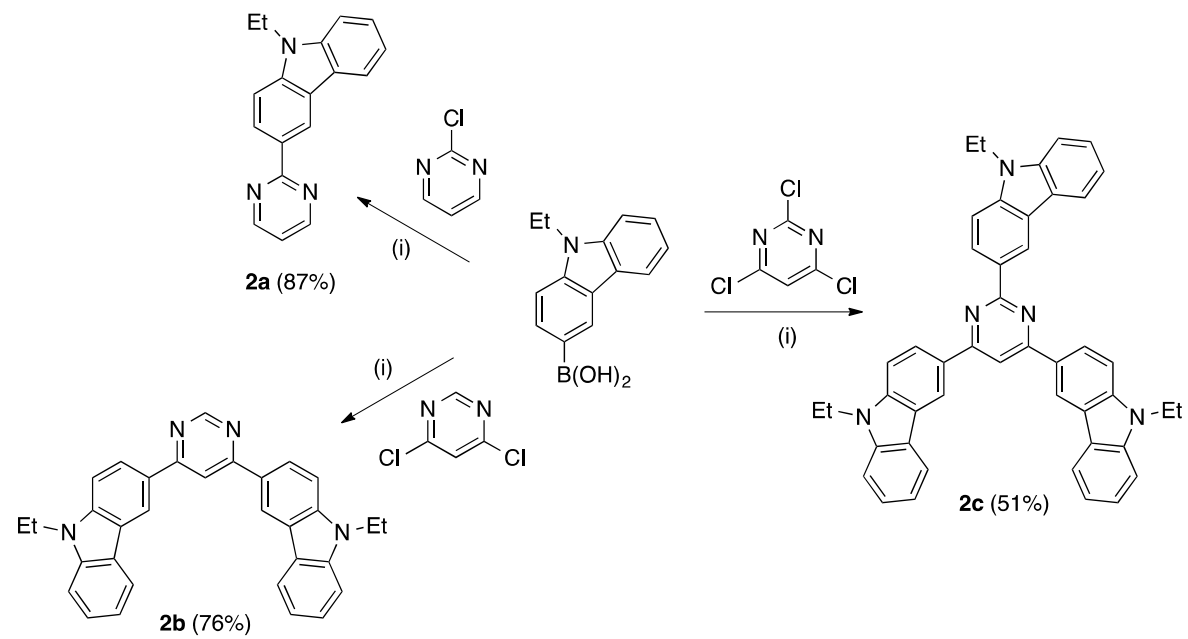

Scheme 1. Preparation of pyrimidines 1 and 2. (i) Toluene, $\mathrm{Pd}\left(\mathrm{PPh}_{3}\right)_{4}, \mathrm{Na}_{2} \mathrm{CO}_{3}$ aq., EtOH, $\Delta, 15 \mathrm{~h}$. 


\subsection{Photophysical Properties in Solution}

The UV-Vis and photoluminescence (PL) spectroscopic data for compounds $\mathbf{1}$ and $\mathbf{2}$ in dichloromethane are presented in Table 1 . The analyses were carried out using low concentration solutions $\left(1.0-2.0 \times 10^{-5} \mathrm{M}\right)$. Self-absorption effects were not observed under the conditions employed. As representative examples, the spectra of compounds 1a-c are shown in Figure 1 (see Figure S1 in the Supporting Information for spectra of compounds $\mathbf{2 a - c}$ ).

Table 1. UV-Vis and photoluminescence (PL) data for compounds $\mathbf{1}$ and $\mathbf{2}$ in $\mathrm{CH}_{2} \mathrm{Cl}_{2}$ solution.

\begin{tabular}{|c|c|c|c|c|c|}
\hline Compd & $\lambda_{\mathrm{abs}}(\mathrm{nm})$ & $\varepsilon\left(\mathrm{mM}^{-1} \mathrm{~cm}^{-1}\right)$ & $\lambda_{\mathrm{em}}(\mathrm{nm})$ & $\Phi_{\mathrm{F}}$ & $\begin{array}{l}\text { Stokes Shift } \\
\left(\mathrm{cm}^{-1}\right)\end{array}$ \\
\hline $1 \mathrm{a}$ & 356,301 & $21.7,13.3$ & 456 & 0.83 & 6160 \\
\hline $1 b$ & 388,301 & $52.0,26.4$ & 486 & 0.86 & 5200 \\
\hline 1c & $376,299,293$ & $76.6,36.7,36.9$ & 475 & 0.52 & 5540 \\
\hline $2 a$ & $323,284,276$ (sh) & $22.6,51.6,33.8$ & 382 & 0.32 & 4780 \\
\hline $2 b$ & $360,348,284$ & $43.2,48.2,50.1$ & 407 & 0.77 & 3210 \\
\hline $2 c$ & 367 (sh) 339, 299, 282 (sh) & $20.4,69.2,84.2,64.1$ & 398 & 0.35 & 2120 \\
\hline
\end{tabular}

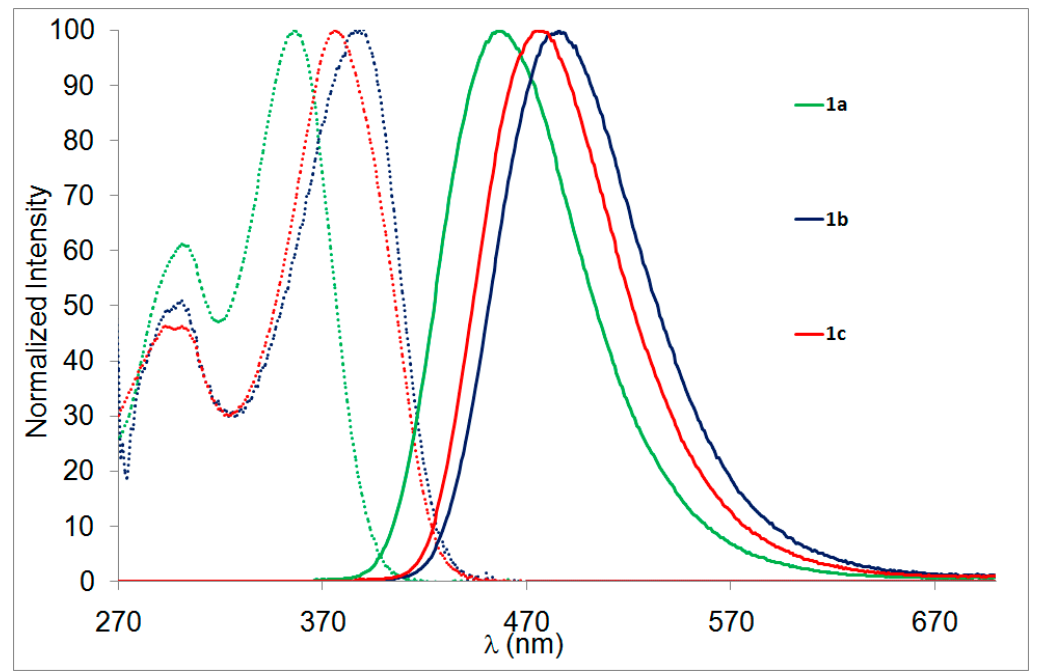

Figure 1. Normalized absorption (dashed lines) and emission (solid lines) spectra of compounds 1a (green), $\mathbf{1 b}$ (blue) and 1c (red) in dichloromethane solution.

Compounds 1, which contain triphenylamine substituents, exhibited red-shifted absorption and emission bands with respect to their 9-ethylcarbazole analogues 2 . This finding indicates that the 9-ethyl-9H-carbazol-3-yl fragment is a weaker electron-donating group than triphenylamine. Triphenylamine derivatives 1 also displayed higher fluorescence quantum yields (up to 0.86 for $\mathbf{1 b}$ ). The 4,6-disubstituted pyrimidines $\mathbf{1} \mathbf{b}$ and $\mathbf{2} \mathbf{b}$ showed a red-shifted emission and an enhanced fluorescence quantum yield in comparison with their C2-monosubstituted analogues 1a and $2 \mathbf{a}$. In contrast, the addition of a third substituent (2,4,6-triarylpyrimidines) led to a slight blue shift in the emission and a decrease in the quantum yield. A similar phenomenon has previously been observed in tristyrylpyrimidines and was attributed to a decrease in the electron-withdrawing character of the pyrimidine central core due to the $\mathrm{C} 2$ electron-donating substituent, which decreases the ICT along the C4 and C6 arms [32].

In an effort to gain further insights into the photophysical properties of these push-pull molecules, in particular to evaluate the ICT upon excitation, the emission behaviour of compounds $\mathbf{1}$ and $\mathbf{2}$ was studied in a variety of different aprotic solvents. The data obtained are summarized in Table 2 . The position of the longest wavelength absorption maximum was not affected significantly but an increase in the solvent polarity, estimated by the Dimroth-Reichardt polarity parameters [46,47], 
resulted in a red-shifted emission (see Figure 2 for compound $\mathbf{1 b}$ and Figures S2-S6 in the Supporting Information for compounds 1a, 1c, and $\mathbf{2 a - c}$ ). This bathochromic shift in the emission band is consistent with stabilization of the highly polar emitting excited state by polar solvents. The solvatochromic shift of the emission band can be used to evaluate the ICT upon excitation. For all compounds, the emission maxima were plotted versus the Dimroth-Reichardt polarity parameter, and in all cases good linearity was found (see Figure S7 in the Supporting Information). The slopes of the corresponding regression lines indicate a stronger ICT for triphenylamine derivatives $\mathbf{1}$ with respect to their 9-ethylcarbazole analogues $\mathbf{2}$. In the triphenylamine series, the slope increased in the order $\mathbf{1 a}<\mathbf{1 c}<\mathbf{1 b}$, thus indicating that the strongest ICT was obtained for the 4,6-disubstituted pyrimidine $\mathbf{1 b}$. In a similar way, the slope increased in the order $\mathbf{2} \mathbf{a}<\mathbf{2} \mathbf{c}<\mathbf{2} \mathbf{b}$ for the 9-ethylcarbazole derivatives.

Table 2. Emission solvatochromism of compounds $\mathbf{1}$ and $\mathbf{2}$ in various aprotic solvents.

\begin{tabular}{|c|c|c|c|c|c|c|c|c|}
\hline Compd & $\begin{array}{c}n \text {-Heptane } \\
30.9^{a}\end{array}$ & Toluene $33.9^{a}$ & $\begin{array}{c}\text { 1,4-Dioxane } \\
36.0^{a}\end{array}$ & THF $37.4^{a}$ & $\begin{array}{c}\mathrm{CHCl}_{3} \\
39.1^{a}\end{array}$ & $\begin{array}{c}\mathrm{CH}_{2} \mathrm{Cl}_{2} \\
40.7^{a}\end{array}$ & $\begin{array}{c}\text { Acetone } \\
42.2^{a}\end{array}$ & $\begin{array}{c}\mathrm{MeCN} \\
45.6^{a}\end{array}$ \\
\hline 1a & 406 & 420 & 429 & 449 & 450 & 456 & 462 & 477 \\
\hline $1 b$ & 418 & 437 & 444 & 464 & 478 & 486 & 498 & 518 \\
\hline 1c & 413 & 432 & 438 & 466 & 466 & 475 & 492 & 508 \\
\hline $2 a$ & $354 / 373$ & $361 / 378$ & $362 / 379$ & 379 & 383 & 382 & 382 & 389 \\
\hline $2 b$ & 371 & 383 & 384 & 395 & 406 & 407 & 413 & 424 \\
\hline $2 c$ & 379 & 384 & 386 & 385 & 398 & 398 & 407 & 415 \\
\hline
\end{tabular}

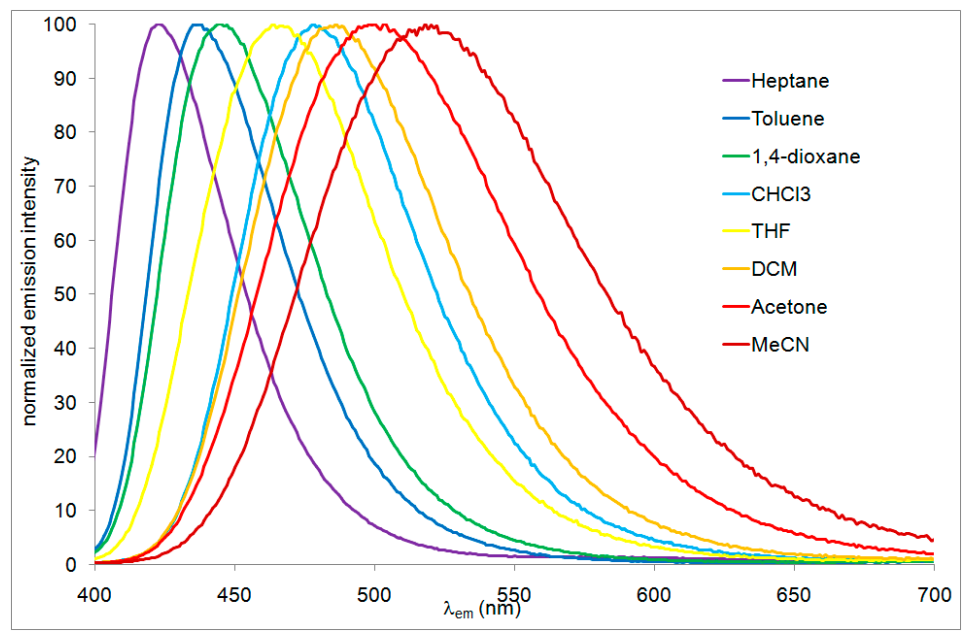

Figure 2. Normalized emission spectra of $\mathbf{1 b}$ in different aprotic solvents.

Photophysical measurements were also performed on a $10^{-2} \mathrm{M}$ solution of camphorsulfonic acid (CSA) in dichloromethane. The results are summarized in Table 3. As one would expect, a bathochromic shift of the charge transfer absorption band was observed for all compounds due to the protonation of the pyrimidine ring $[45,48]$. This was associated with a dramatic quenching of the fluorescence for the triphenylamine derivatives. As a consequence, emission bands could not be identified for compounds 1a and 1c, whereas for $\mathbf{1 b}$ a low intensity emission in the red region was detected $\left(\lambda_{\max }=\right.$ $\left.651 \mathrm{~nm}, \Phi_{\mathrm{F}}<0.01\right)$. It is worth noting that the protonated form of $\mathbf{1 b}$ was more emissive in chloroform solution $\left(\lambda_{\mathrm{abs}}=493 \mathrm{~nm}, \lambda_{\mathrm{em}}=625 \mathrm{~nm}, \Phi_{\mathrm{F}}=0.11\right)$. In contrast, the 9-ethylcarbazole derivatives $2 \mathrm{~b}$ and $2 \mathrm{c}$ remained fluorescent and they emitted green-yellow light with high emission quantum yields $\left(\Phi_{\mathrm{F}}=0.63\right.$ and 0.45 , respectively). The decay lifetimes $(\tau)$ were determined to be $3.6 \mathrm{~ns}$ and $4.2 \mathrm{~ns}(\tau$ values for the neutral molecules were $1.8 \mathrm{~ns}$ and $1.7 \mathrm{~ns}$, respectively). Surprisingly, 2a was not emissive in acidified dichloromethane. The effect of protonation was studied in a more detailed way by titration of solutions of compounds $\mathbf{1 b}, \mathbf{2} \mathbf{b}$ and $\mathbf{2} \mathbf{c}$ with CSA. The changes observed in the UV-vis and emission spectra for $\mathbf{2} \mathbf{b}$ are illustrated in Figures 3 and 4 , respectively (see the Supporting Information for data 
for compounds $\mathbf{1 b}$ and $\mathbf{2} \mathbf{c}$ ). The absorption spectra showed the progressive disappearance of the charge transfer absorption band of the neutral form, whereas a red-shifted charge transfer absorption band for the protonated form progressively appeared. The presence of an isosbestic point is evident and this is characteristic of an equilibrium between two species (Figure 3). The same trend was observed in the emission spectra: the addition of CSA led to the progressive disappearance of the emission band of the neutral form and this was associated with the enhancement of a new red-shifted band corresponding to the emission of the protonated form with an isoemissive point (Figure 4).

Table 3. UV/Vis and PL data for compounds 1 and 2 in acid solution $\left(10^{-2} \mathrm{M} \mathrm{CSA}\right.$ in $\left.\mathrm{CH}_{2} \mathrm{Cl}_{2}\right)$.

\begin{tabular}{cccccc}
\hline Compd & $\boldsymbol{\lambda}_{\text {abs }} \mathbf{( n m )}$ & $\varepsilon\left(\mathbf{m M}^{-\mathbf{1}} \mathbf{c m}^{\mathbf{- 1})}\right.$ & $\boldsymbol{\lambda}_{\mathbf{e m}} \mathbf{( n m )}$ & $\boldsymbol{\Phi}_{\mathbf{F}}$ & $\begin{array}{c}\text { Stokes Shift } \\
\left(\mathbf{c m}^{\mathbf{1}} \mathbf{)}\right.\end{array}$ \\
\hline $\mathbf{1 a}$ & $424,373(\mathbf{s h}), 268$ & $17.2,9.3,30.5$ & - & - & - \\
$\mathbf{1 b}$ & 488 & 48.3 & 651 & $<0.01$ & 5130 \\
$\mathbf{1 c}$ & $486,375,274$ & $68.2,30.4,88.5$ & - & - & - \\
$\mathbf{2 a}$ & 396 & 27.3 & - & - & - \\
$\mathbf{2 b}$ & $444,390,285$ & $63.9,28.0,64.3$ & 519 & 0.63 & 3250 \\
$\mathbf{2 c}$ & 443,330 & $41.9,29.0$ & 552 & 0.45 & 4460 \\
\hline
\end{tabular}

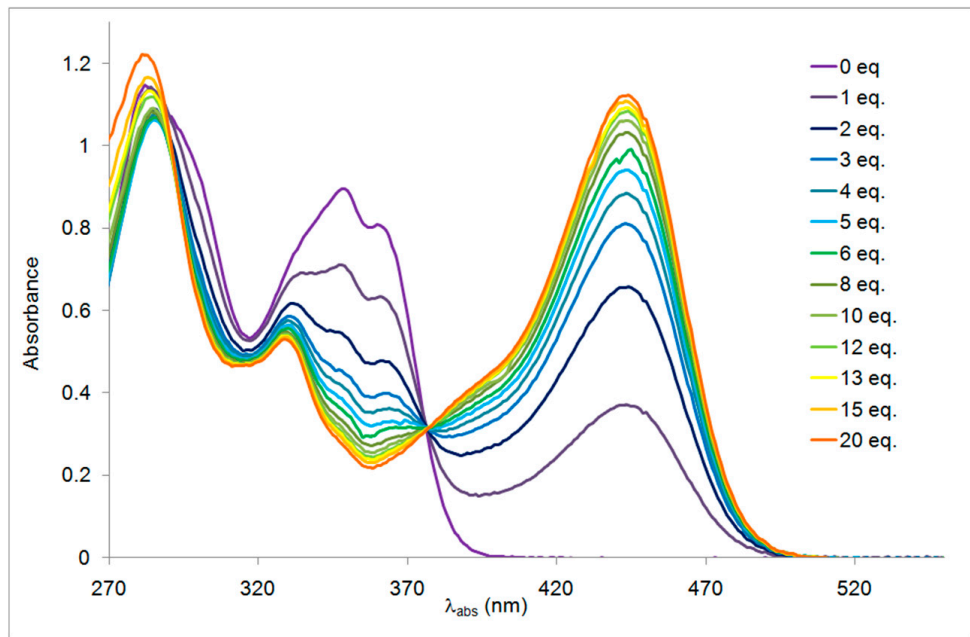

Figure 3. Changes in the absorption spectra of a dichloromethane solution of $2 \mathbf{b}\left(c=1.87 \times 10^{-5} \mathrm{M}\right)$ upon addition of CSA (0-20 equivalents).

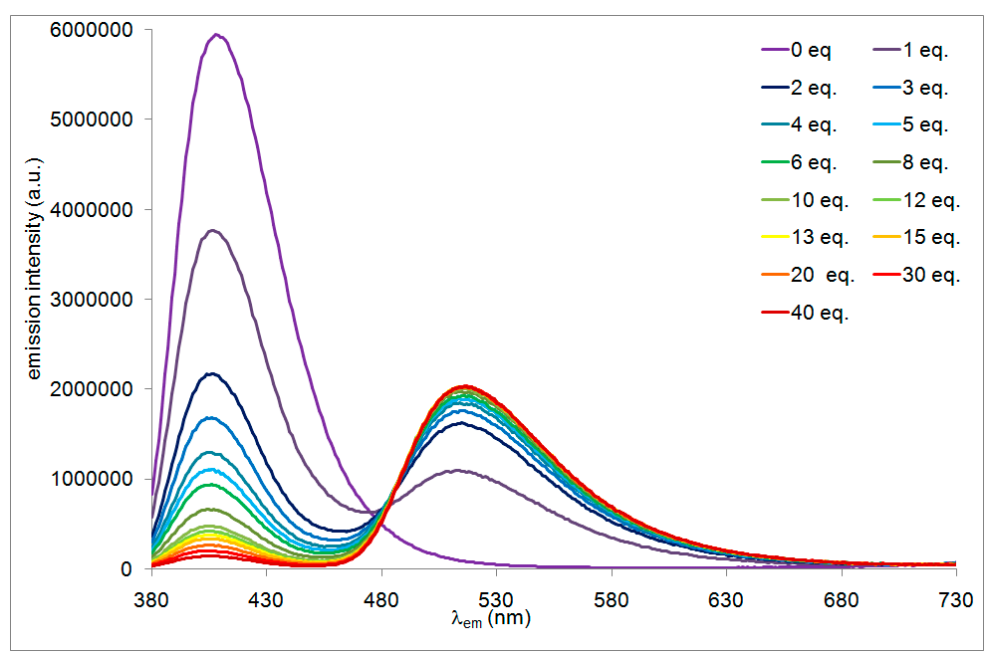

Figure 4. Changes in the emission spectra of a dichloromethane solution of $\mathbf{2 b}\left(c=1.97 \times 10^{-5} \mathrm{M}\right)$ upon addition of CSA (0-40 equivalents), $\lambda_{\mathrm{exc}}=370 \mathrm{~nm}$. 
The coexistence of both neutral and protonated species with complementary emitting colors in the solution enabled white light emission to be achieved under UV-irradiation. Thus, compound 2c emitted violet light at $\lambda_{\max }=398 \mathrm{~nm}$ and this turned to green-yellow at $\lambda_{\max }=552 \mathrm{~nm}$ upon protonation. Excitation at $370 \mathrm{~nm}$ led to the observation of white light after the addition of 45 equivalents of CSA to a $1.25 \times 10^{-5} \mathrm{M}$ solution of $\mathbf{2 c}$ in dichloromethane (Figure 5). The same phenomenon was also observed for compounds $\mathbf{1 b}$ and $\mathbf{2 b}$ (Figures S11 and S12 of the Supporting Information, respectively). For $\mathbf{1 b}$ and $\mathbf{2 c}$, the calculated CIE chromaticity coordinates (Table 4) were close to those of pure white light $(0.33,0.33)$.

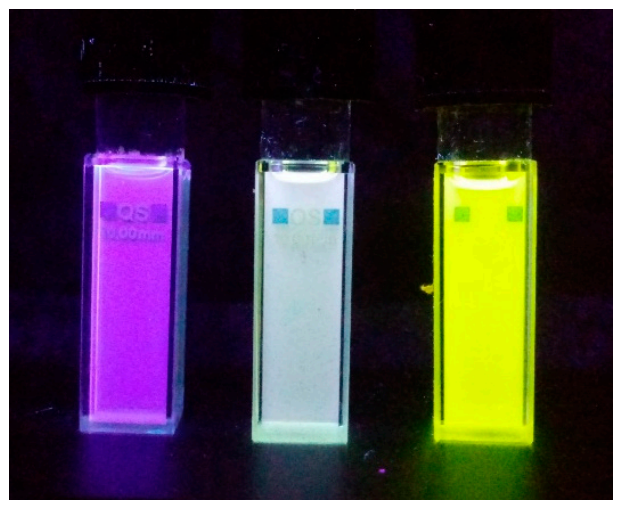

Figure 5. Changes in the color of a dichloromethane solution of $2 c\left(c=1.25 \times 10^{-5} \mathrm{M}\right)$ after the addition of 45 equivalents (middle) and in $10^{-2} \mathrm{M}$ CSA (right). Photographs were taken in the dark upon irradiation with a hand-held UV lamp $\left(\lambda_{\mathrm{em}}=366 \mathrm{~nm}\right)$.

Table 4. CIE coordinates for compounds 1 and 2 in solution.

\begin{tabular}{cccc}
\hline & \multicolumn{3}{c}{ Chromaticity Coordinates (x, y) } \\
\cline { 2 - 4 } Compd & Neutral Form & Protonated Form & $\begin{array}{c}\text { Mixture of Neutral and } \\
\text { Protonated Forms }\end{array}$ \\
\hline $\mathbf{1 a} \mathbf{a}^{a}$ & $(0.15,0.15)$ & - & - \\
$\mathbf{1} \mathbf{b}^{b}$ & $(0.18,0.33)$ & $(0.62,0.37)$ & $(0.32,0.34)^{c}$ \\
$\mathbf{1} \mathbf{c}^{a}$ & $(0.16,0.25)$ & - & - \\
$\mathbf{2} \mathbf{a}^{a}$ & $(0.18,0.04)$ & - & - \\
$\mathbf{2} \mathbf{b}^{a}$ & $(0.16,0.03)$ & $(0.29,0.59)$ & $(0.24,0.39)^{d}$ \\
$\mathbf{2}^{a}$ & $(0.17,0.04)$ & $(0.42,0.56)$ & $(0.30,0.34)^{e}$ \\
\hline
\end{tabular}

${ }^{a}$ In dichloromethane solution $\left(c=1.0-2.0 \times 10^{-5} \mathrm{M}\right) \cdot{ }^{b}$ In chloroform solution $\left(c=9.76 \times 10^{-6} \mathrm{M}\right) \cdot{ }^{c} 50$ equivalents of $\mathrm{CSA}, \lambda_{\mathrm{exc}}=400 \mathrm{~nm} .{ }^{d} 2$ equivalents of CSA, $\lambda_{\mathrm{exc}}=370 \mathrm{~nm} .{ }^{e} 45$ equivalents of CSA, $\lambda_{\mathrm{exc}}=370 \mathrm{~nm}$.

\subsection{Photophysical Properties in Solid State}

Filter paper pieces covered with $\mathbf{2 b}$ and $\mathbf{2} \mathbf{c}$ in the absence and presence of different amounts of CSA were prepared by immersion of the filter paper into a dichloromethane solution of the appropriate compound ( $1 \mathrm{wt} \%$ doped on polystyrene). The samples were dried in air. The fluorescence spectra of the samples were acquired and emission maxima in the violet region at $\lambda_{\max }=405 \mathrm{~nm}$ and $406 \mathrm{~nm}$, respectively, were determined in the absence of acid. The intensities of these bands gradually decreased on increasing the amount of CSA, whereas a distinctly novel enhanced emission appeared in the green-yellow region $\left(\lambda_{\max }=544 \mathrm{~nm}\right.$ for $2 \mathbf{b}$ and $\lambda_{\max }=554 \mathrm{~nm}$ for $\left.2 \mathrm{c}\right)$. After careful tuning of the number of equivalents of CSA, white light was observed due to the simultaneous emission from both the neutral and protonated compounds. These significant emission changes were easily followed by the naked eye under UV irradiation (Figure 6 and Figure S13 in the Supporting Information). Energy transfer between neutral and protonated molecules has been suggested for related systems [49]. 


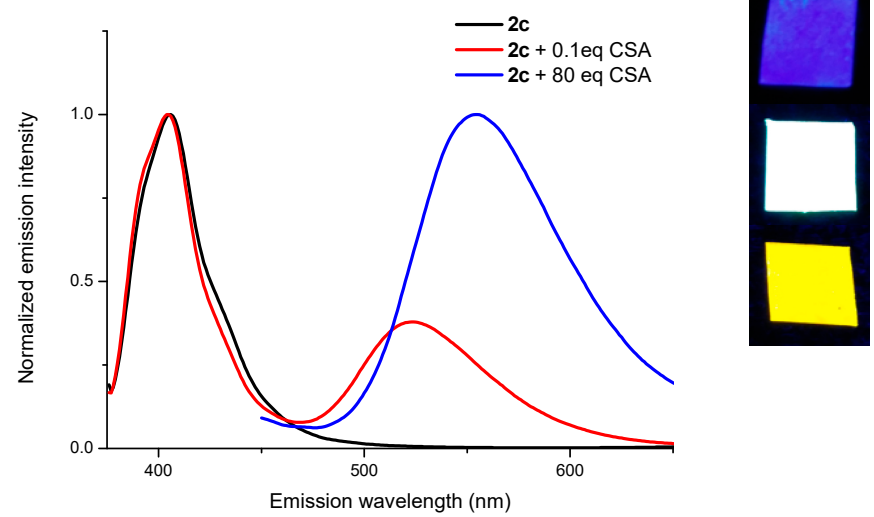

Figure 6. Fluorescence spectra $\left(\lambda_{\mathrm{exc}}=365 \mathrm{~nm}\right)$ and changes in the colour of filter paper samples after immersion into a dichloromethane solution of polystyrene doped with $2 \mathrm{c}(1 \mathrm{wt} \%)$ in the absence (top) and presence of 0.1 equivalents (middle) and 80 equivalents (bottom) of CSA. Photographs were taken in the dark upon irradiation with a hand-held UV lamp $\left(\lambda_{\mathrm{em}}=366 \mathrm{~nm}\right)$.

\section{Materials and Methods}

\subsection{General Information}

All solvents were reagent grade for synthesis and spectroscopic grade for photophysical measurements. The starting materials were purchased from Sigma-Aldrich (St Louis, MO, USA) or Alfa Aesar (Haverhill, MA, USA) and were used without further purification. For air- and moisture-sensitive reactions, all glassware was flame-dried and cooled under nitrogen. NMR spectra were recorded in $\mathrm{CDCl}_{3}$ on a Bruker Avance 300 spectrometer $\left({ }^{1} \mathrm{H}\right.$ at $300 \mathrm{MHz}$ and ${ }^{13} \mathrm{C}$ at $75 \mathrm{MHz}$, Billerica, MA, USA). The chemical shifts $\delta$ are reported in ppm and are referenced to the residual protons of the deuterated solvent or carbon nuclei $\left({ }^{1} \mathrm{H}, \delta=7.27 \mathrm{ppm} ;{ }^{13} \mathrm{C}, \delta=77.0 \mathrm{ppm}\right)$. The coupling constants $J$ are given in $\mathrm{Hz}$. In the ${ }^{1} \mathrm{H}-\mathrm{NMR}$ spectra, the following abbreviations are used to describe the peak patterns: $s$ (singlet), $d$ (doublet), $d d$ (doublet of doublets), $t$ (triplet), $m$ (multiplet). In the ${ }^{13} \mathrm{C}-\mathrm{NMR}$ spectra, the nature of the carbons $\left(\mathrm{C}, \mathrm{CH}, \mathrm{CH}_{2}\right.$ or $\left.\mathrm{CH}_{3}\right)$ was determined by performing a JMOD experiment. Melting points $\left({ }^{\circ} \mathrm{C}\right)$ were measured on a Kofler hot-stage with a precision of 2 degrees $\left( \pm 2{ }^{\circ} \mathrm{C}\right)$. High-resolution mass analyses were performed at the 'Centre Régional de Mesures Physiques de l'Ouest' (CRMPO, Université de Rennes 1, Rennes, France) using a Bruker MicroTOF-Q II apparatus. Analytical thin layer chromatography (TLC) was performed on 60 F254 silica gel plates (Merck, Darmstadt, Germany), and compounds were visualized by irradiation with UV light at 254 and $365 \mathrm{~nm}$. Flash chromatography was performed using silica SI 60 (60-200 mesh ASTM, Acros, Waltham, MA, USA). UV-visible and fluorescence spectroscopy studies were conducted on a Spex Fluoromax-3 spectrophotometer (Jobin-Yvon Horiba, Kyoto, Japan). Compounds were excited at their absorption maxima (band of lowest energy) to record the emission spectra. All solutions were measured with optical densities below 0.1 . Fluorescence quantum yields $( \pm 10 \%)$ were determined relative to 9,10-bis(phenylethynyl)anthracene in cyclohexane $\left(\Phi_{\mathrm{F}}=1.00\right)$. Stokes shifts were calculated considering the lowest energetic absorption band.

\subsection{General Procedure for Suzuki Cross-coupling Reactions}

A stirred mixture of the chloropyrimidine derivative $(1 \mathrm{mmol})$, arylboronic acid (1.2 mmol per chlorine atom), $\mathrm{Pd}\left(\mathrm{PPh}_{3}\right)_{4}(0.05 \mathrm{mmol}$ per chlorine atom), $1 \mathrm{M}$ aqueous sodium carbonate $(1.2 \mathrm{mmol}$, $1.2 \mathrm{~mL}$ per chlorine atom), and ethanol $(1.5 \mathrm{~mL})$ in degassed toluene $(15 \mathrm{~mL})$ was heated at reflux under nitrogen for $15 \mathrm{~h}$ in a Schlenk tube. The reaction mixture was cooled, filtered, and dissolved with a mixture of AcOEt and water 1:1 $(50 \mathrm{~mL})$ and the organic layer was separated. The aqueous layer was extracted with AcOEt $(2 \times 25 \mathrm{~mL})$. The combined organic extracts were dried with $\mathrm{MgSO}_{4}$ and the solvents were evaporated. 
2-(4-Diphenylaminophenyl)pyrimidine (1a). The title compound was obtained according to the general procedure and purified by column chromatography $\left(\mathrm{SiO}_{2}, \mathrm{AcOEt} /\right.$ petroleum ether, 3:7). Beige solid. Yield: $75 \%$ (241 mg). Mp: $173-174{ }^{\circ} \mathrm{C}$ (lit.: 168-169 ${ }^{\circ} \mathrm{C}$ ) [50]. ${ }^{1} \mathrm{H}-\mathrm{NMR}\left(300 \mathrm{MHz}, \mathrm{CDCl}_{3}\right): \delta 7.17-7.05$ $(\mathrm{m}, 9 \mathrm{H}), 7.31-7.27(\mathrm{~m}, 4 \mathrm{H}), 8.28(\mathrm{~d}, 2 \mathrm{H}, \mathrm{J}=9.0 \mathrm{~Hz}), 8.74(\mathrm{~d}, 2 \mathrm{H}, J=4.8 \mathrm{~Hz}) .{ }^{13} \mathrm{C}-\mathrm{NMR}\left(75 \mathrm{MHz}, \mathrm{CDCl}_{3}\right)$ : $\delta 118.2,122.1,123.6,125.2,129.2,129.4,130.9,147.3,150.3,157.1,164.5$.

4,6-bis(4-Diphenylaminophenyl)pyrimidine (1) $)$. The title compound was obtained according to the general procedure and purified by column chromatography $\left(\mathrm{SiO}_{2}\right.$, AcOEt/petroleum ether, 3:7). Yellow solid. Yield: 87\% (492 mg). Mp: 230-231 ${ }^{\circ} \mathrm{C} .{ }^{1} \mathrm{H}-\mathrm{NMR}\left(300 \mathrm{MHz}, \mathrm{CDCl}_{3}\right): \delta 7.17-7.07(\mathrm{~m}, 16 \mathrm{H})$, 7.33-7.27 (m, 8H), $7.93(\mathrm{~d}, 1 \mathrm{H}, J=1.2 \mathrm{~Hz}), 7.99(\mathrm{~d}, 4 \mathrm{H}, J=9.0 \mathrm{~Hz}), 9.17(\mathrm{~d}, 1 \mathrm{H}, J=1.2 \mathrm{~Hz}) .{ }^{13} \mathrm{C}-\mathrm{NMR}$ $\left(75 \mathrm{MHz} \mathrm{CDCl}_{3}\right): \delta 110.9,122.0,123.9,125.3,128.1,129.5,129.9,147.1,150.4,159.0,163.7$. HRMS (ESI/ASAP), $m / z$ calculated for $\mathrm{C}_{40} \mathrm{H}_{31} \mathrm{~N}_{4}[\mathrm{M}+\mathrm{H}]^{+} 567.2543$, found 567.2546.

2,4,6-tris(4-Diphenylaminophenyl)pyrimidine (1c). The title compound was obtained according to the general procedure and purified by column chromatography $\left(\mathrm{SiO}_{2}, \mathrm{AcOEt} /\right.$ petroleum ether, 3:7). Yellow solid. Yield: $65 \%(526 \mathrm{mg})$. Mp: $>260{ }^{\circ} \mathrm{C} .{ }^{1} \mathrm{H}-\mathrm{NMR}\left(300 \mathrm{MHz}, \mathrm{CDCl}_{3}\right): \delta 7.11-7.06(\mathrm{~m}, 6 \mathrm{H}), 7.18-7.15$ $(\mathrm{m}, 18 \mathrm{H}), 7.32-7.27(\mathrm{~m}, 12 \mathrm{H}), 7.78(\mathrm{~s}, 1 \mathrm{H}), 8.11(\mathrm{~d}, 4 \mathrm{H}, \mathrm{J}=8.7 \mathrm{~Hz}), 8.51(\mathrm{~d}, 2 \mathrm{H}, \mathrm{J}=8.7 \mathrm{~Hz}) .{ }^{13} \mathrm{C}-\mathrm{NMR}$ $\left(75 \mathrm{MHz}, \mathrm{CDCl}_{3}\right): \delta 107.9,122.2,122.4,123.3,123.7,124.9,125.2,128.1,129.3,129.4,130.8,132.1,147.2$, $147.4,149.9,150.2,163.7,164.0$ HRMS (ESI/ASAP), $m / z$ calculated for $\mathrm{C}_{58} \mathrm{H}_{44} \mathrm{~N}_{5}[\mathrm{M}+\mathrm{H}]^{+} 810.3591$, found 810.3591 .

2-(9-Ethyl-9H-carbazol-3-yl)pyrimidine (2a). The title compound was obtained according to the general procedure and purified by column chromatography $\left(\mathrm{SiO}_{2}, \mathrm{AcOEt} /\right.$ petroleum ether, 3:7). Beige solid. Yield: 87\% (238 mg). Mp: 136-137 ${ }^{\circ} \mathrm{C} .{ }^{1} \mathrm{H}-\mathrm{NMR}\left(300 \mathrm{MHz}, \mathrm{CDCl}_{3}\right): \delta 1.47(\mathrm{t}, 3 \mathrm{H}, J=7.2 \mathrm{~Hz}), 4.41(\mathrm{q}$, $6 \mathrm{H}, J=7.2 \mathrm{~Hz}), 7.14(\mathrm{t}, 1 \mathrm{H}, J=4.8 \mathrm{~Hz}), 7.30-7.27(\mathrm{~m}, 1 \mathrm{H}), 7.52-7.42(\mathrm{~m}, 3 \mathrm{H}), 8.22(\mathrm{~d}, 1 \mathrm{H}, J=7.8 \mathrm{~Hz})$, $8.61(\mathrm{~d}, 1 \mathrm{H}, J=7.8 \mathrm{~Hz}), 8.82(\mathrm{~d}, 2 \mathrm{H}, J=5.1 \mathrm{~Hz}), 9.22(\mathrm{~s}, 2 \mathrm{H}) .{ }^{13} \mathrm{C}-\mathrm{NMR}\left(75 \mathrm{MHz} \mathrm{CDCl}_{3}\right): \delta 13.9,37.7$, 108.4, 108.7, 118.1, 119.5, 120.8, 121.0, 123.3, 123.5, 126.0, 126.2, 128.6, 140.6, 141.8, 157.2, 165.6. HRMS (ESI/ASAP), $m / z$ calculated for $\mathrm{C}_{18} \mathrm{H}_{16} \mathrm{~N}_{3}[\mathrm{M}+\mathrm{H}]^{+} 274.1338$, found 274.1343.

4,6-bis(9-Ethyl-9H-carbazol-3-yl)pyrimidine (2b). The title compound was obtained according to the general procedure and purified by column chromatography $\left(\mathrm{SiO}_{2}, \mathrm{AcOEt} /\right.$ petroleum ether, 1:1). Pale yellow solid. Yield: $76 \%$ (352 mg). Mp: 170-171 ${ }^{\circ} \mathrm{C}$ (lit.: 176-177 ${ }^{\circ} \mathrm{C}$ ) [45]. ${ }^{1} \mathrm{H}-\mathrm{NMR}\left(300 \mathrm{MHz}, \mathrm{CDCl}_{3}\right)$ : $\delta 1.45(\mathrm{t}, 6 \mathrm{H}, J=6.9 \mathrm{~Hz}), 4.33(\mathrm{q}, 4 \mathrm{H}, J=6.9 \mathrm{~Hz}), 7.53-7.30(\mathrm{~m}, 8 \mathrm{H}), 8.32-8.24(\mathrm{~m}, 5 \mathrm{H}), 8.99(\mathrm{~s}, 2 \mathrm{H}), 9.36$ (s, 1H). ${ }^{13} \mathrm{C}-\mathrm{NMR}\left(75 \mathrm{MHz}, \mathrm{CDCl}_{3}\right): \delta 13.8,37.7,108.6,108.8,111.5,119.6,119.7,120.8,123.2,123.5$, $124.9,126.2,127.9,140.6,141.6,159.0,164.8$.

2,4,6-tris(9-Ethyl-9H-carbazol-3-yl)pyrimidine (2c). The title compound was obtained according to the general procedure and purified by column chromatography $\left(\mathrm{SiO}_{2}, \mathrm{AcOEt} /\right.$ petroleum ether, 3:7) followed by recrystallization from $\mathrm{CH}_{2} \mathrm{Cl}_{2} / n$-heptane. Pale yellow solid. Yield: $51 \%$ (330 mg). $\mathrm{Mp}$ : 176-177 ${ }^{\circ} \mathrm{C} .{ }^{1} \mathrm{H}-\mathrm{NMR}\left(300 \mathrm{MHz}, \mathrm{CDCl}_{3}\right): \delta 1.52(\mathrm{t}, 9 \mathrm{H}, J=6.3 \mathrm{~Hz}), 4.46(\mathrm{q}, 6 \mathrm{H}, \mathrm{J}=7.2 \mathrm{~Hz}), 7.37-7.33(\mathrm{~m}$, $3 \mathrm{H}), 7.62-7.47(\mathrm{~m}, 9 \mathrm{H}), 8.22(\mathrm{~d}, 1 \mathrm{H}, J=2.4 \mathrm{~Hz}), 8.38-8.33(\mathrm{~m}, 3 \mathrm{H}), 8.59(2 \mathrm{H}, \mathrm{d}, J=8.7 \mathrm{~Hz}), 9.04(1 \mathrm{H}, \mathrm{dd}$, $\left.J_{1}=8.7 \mathrm{~Hz}, J_{2}=1.2 \mathrm{~Hz}\right), 9.14(\mathrm{~s}, 2 \mathrm{H}), 9.59(\mathrm{~s}, 1 \mathrm{H}) .{ }^{13} \mathrm{C}-\mathrm{NMR}\left(75 \mathrm{MHz}, \mathrm{CDCl}_{3}\right): \delta 13.9,37.8,108.2,108.7$, $108.8,119.2,119.4,119.8,120.8,120.9,121.2,123.2,123.4,123.5,123.8,125.4,125.7,126.1,126.8,129.1$, 130.0, 140.6, 141.6. HRMS (ESI/ASAP), $m / z$ calculated for $\mathrm{C}_{46} \mathrm{H}_{38} \mathrm{~N}_{5}[\mathrm{M}+\mathrm{H}]^{+}$660.3122, found 660.3122 .

\section{Conclusions}

Push-pull pyrimidines substituted with a different number of either triphenylamine or 9-ethylcarbazole groups were prepared by Suzuki cross-coupling reaction from the corresponding chloropyrimidines and boronic acids. The molecules presented absorption wavelengths in the UV region and emitted violet-blue light in dichloromethane solution with a higher fluorescence quantum yield and a stronger ICT observed for the triphenylamine derivatives. The addition of acid was accompanied by a dramatic quenching of the fluorescence except for the 9-ethylcarbazole derivatives $\mathbf{2 b}$ and $\mathbf{2 c}$ (and partially for $\mathbf{1 b}$ ). In these cases, protonation led to the progressive disappearance of the 
emission band and the appearance of a new red-shifted complementary emitting band. Thus, white photoluminescence could be obtained by controlled protonation. White emission was also achieved in solid state.

Supplementary Materials: The following material is available online: Figure S1: absorption and emission spectra of compounds $\mathbf{2 a}-\mathbf{c}$ in dichloromethane solution; Figures S2-S6: emission spectra of 1a, 1c, and 2a-c in different aprotic solvents; Figure S7: emission maxima as a function of the Dimroth-Reichardt polarity parameter $\mathrm{E}_{\mathrm{T}}(30)$ for compounds $\mathbf{1}$ and 2; Figures S8-S10: changes in the absorption and emission spectra of a solution of $\mathbf{1} \mathbf{b}$ and $\mathbf{2 b}$ upon addition of CSA; Figures S11 and S12: changes in the color of a solution of $\mathbf{1 b}$ and $\mathbf{2} \mathbf{b}$ after the addition of CSA; Figure S13: fluorescence spectra and changes in the color of $\mathbf{2 b}$ in solid state after the addition of CSA; Figures S14-S23: ${ }^{1} \mathrm{H},{ }^{13} \mathrm{C}-\mathrm{NMR}$ and HRMS spectra of compounds $\mathbf{1}$ and $\mathbf{2}$.

Author Contributions: Conceptualization, S.A. and J.R.-L.; Formal analysis, S.A. and J.R.-L.; Funding acquisition, J.R.-L. and F.R.-1.G.; Investigation, S.A., J.R.-L., M.L. and R.P.-P.; Supervision, S.A. and J.R.-L.; Writing-original draft, S.A.; Writing-review \& editing, J.R.-L. and F.R.-l.G.

Funding: This research was funded by the Junta de Comunidades de Castilla-La Mancha/FEDER (project SBPLY/17/180501/000214) and the Ministerio de Economía y Competitividad/Agencia Estatal de Investigación/FEDER (project CTQ2017-84561-P).

Acknowledgments: Olivier Mongin, Institut des Sciences Chimiques de Rennes, is acknowledged for helpful discussions.

Conflicts of Interest: The authors declare no conflict of interest.

\section{References}

1. Achelle, S.; Rodríguez-López, J.; Robin-le Guen, F. Photoluminescence properties of aryl- arylvinyl- and arylethynylpyrimidine derivatives. ChemistrySelect 2018, 3, 1852-1885. [CrossRef]

2. Aranda, A.I.; Achelle, S.; Hammerer, F.; Mahuteau-Betzer, F.; Teulade-Fichou, M.-P. Vinyl-diazine triphenylamines and their $N$-methylated derivatives: synthesis, photophysical properties and application for staining DNA. Dyes Pigm. 2012, 95, 400-407. [CrossRef]

3. Lipunova, G.N.; Nosova, E.V.; Charushin, V.N.; Chupakhin, O.N. Functionalized quinazolines and pyrimidines for optoelectronics. Curr. Org. Synth. 2018, 15, 793-814. [CrossRef]

4. Achelle, S.; Plé, N. Pyrimidine ring as building block for the synthesis of functionalized $\pi$-conjugated materials. Curr. Org. Synth. 2012, 9, 163-187. [CrossRef]

5. Li, L.; Ge, J.; Wu, H.; Xu, Q.-H.; Yao, S.Q. Organelle-specific detection of phosphatase activities with two-photon fluorogenic probes in cells and tissues. J. Am. Chem. Soc. 2012, 134, 12157-12167. [CrossRef] [PubMed]

6. Na, Z.; Li, L.; Uttamchandani, M.; Yao, S.Q. Microarray-guided discovery of two-photon (2P) small molecule probes for live-cell imaging of cysteinyl cathepsin activities. Chem. Commun. 2012, 48, 7304-7306. [CrossRef] [PubMed]

7. Zhang, Q.; Tian, X.; Hu, Z.; Brommesson, C.; Wu, J.; Zhou, H.; Yang, J.; Sun, Z.; Tian, Y.; Uvdal, K. Nonlinear optical response and two-photon biological applications of a new family of imidazole-pyrimidine derivatives. Dyes Pigm. 2016, 126, 286-295. [CrossRef]

8. Liu, B.; Zhang, H.-L.; Liu, J.; Zhao, Y.-D.; Luo, Q.-M.; Huang, Z.-L. Novel pyrimidine-based amphiphilic molecules: synthesis, spectroscopic properties and applications in two-photon fluorescence imaging. J. Mater. Chem. 2007, 17, 2921-2929. [CrossRef]

9. Malval, J.-P.; Achelle, S.; Bodiou, L.; Spangenberg, A.; Gomez, L.C.; Soppera, O.; Robin-le Guen, F. Two-photon absorption in a conformationally twisted $\mathrm{D}-\pi$-A oligomer: a synergic photosensitizing approach for multiphoton lithography. J. Mater. Chem. C 2014, 4, 7869-7880. [CrossRef]

10. Li, L.; Tian, Y.; Yang, J.-X.; Sun, P.-P.; Wu, J.-Y.; Zhou, H.-P.; Zhang, S.-Y.; Jin, B.-K.; Xing, X.-J.; Wang, C.-K.; et al. Facile synthesis and systematic investigations of a series of novel bent-shaped two-photon absorption chromophores based on pyrimidine. Chem. Asian J. 2009, 4, 668-680. [CrossRef]

11. Serevičius, T.; Bučiūnas, T.; Bucevičius, J.; Dodonova, J.; Tumkevičius, S.; Kazlauskas, K.; Juršènas, S. Room-temperature phosphorescence vs. thermally activated delayed fluorescence in cabazole pyrimidine cored compounds. J. Mater. Chem. C 2018, 6, 11128-11136. [CrossRef] 
12. Li, B.; Li, Z.; Hu, T.; Zhang, Y.; Wang, Y.; Yi, Y.; Guo, F.; Zhao, L. Highly efficient blue organic light-emitting diodes from pyrimidine-based thermally activated delayed fluorescence emitters. J. Mater. Chem. C 2018, 6, 2351-2359. [CrossRef]

13. Komatsu, R.; Sasabe, H.; Kido, J. Recent progress of pyrimidine derivatives for high-performance organic light-emitting devices. J. Photonics Energy 2018, 8, 032108. [CrossRef]

14. Komatsu, R.; Ohsawa, T.; Sasabe, H.; Nakao, K.; Hayasaka, Y.; Kido, J. Manipulating the electronic excited state energies of pyrimidine-based thermally activated delayed fluorescence emitters to realize efficient deep-blue emission. ACS Appl. Mater. Interfaces 2017, 9, 4742-4749. [CrossRef] [PubMed]

15. Nakao, K.; Sasabe, H.; Komatsu, R.; Hayasaka, Y.; Ohsawa, T.; Kido, J. Unlocking the potential of pyrimidine conjugate emitters to realize high-performance organic light-emitting devices. Adv. Opt. Mater. 2017, 5, 1600843. [CrossRef]

16. Durand, R.J.; Gauthier, S.; Achelle, S.; Groizard, T.; Kahlal, S.; Saillard, J.-Y.; Barsella, A.; le Poul, P.; Robin-le Guen, F. Push-pull D- $\pi$-Ru- $\pi$-A chromophores: synthesis and electrochemical, photophysical and second-order nonlinear optical properties. Dalton Trans. 2018, 47, 3965-3975. [CrossRef] [PubMed]

17. Achelle, S.; Kahlal, S.; Barsella, A.; Saillard, J.-Y.; Che, X.; Vallet, J.; Bureš, F.; Caro, B.; Robin-le Guen, F. Improvement of the quadratic non-linear optical properties of pyrimidine chromophores by N-methylation and tungsten pentacarbonyl complexation. Dyes Pigm. 2015, 113, 562-570. [CrossRef]

18. Sun, H.; Liu, D.; Wang, T.; Li, P.; Bridgmohan, C.N.; Li, W.; Lu, T.; Hu, W.; Wang, L.; Zhou, X. Charge-separated sensitizers with enhanced intramolecular charge transfer for dye-sensitized solar cells: Insight from structure-performance relationships. Org. Electron. 2018, 61, 35-45. [CrossRef]

19. Verbitskiy, E.V.; Cheprakova, E.M.; Subbotina, J.O.; Schepochkin, A.V.; Slepukhin, P.A.; Rusinov, G.L.; Charushin, V.N.; Chupakhin, O.N.; Makarova, N.I.; Metelitsa, A.V.; et al. Synthesis, spectral and electrochemical properties of pyrimidine-containing dyes as photosensitizers for dye-sensitized solar cells. Dyes Pigm. 2014, 100, 201-204. [CrossRef]

20. Achelle, S.; Robin-le Guen, F. Emission properties of diazine chromophores: structure-properties relationship. J. Photochem. Photobiol. A 2017, 348, 281-286. [CrossRef]

21. Schomaker, J.M.; Delia, T.J. Arylation of halogenated pyrimidines via a Suzuki coupling reaction. J. Org. Chem. 2001, 66, 7125-7128. [CrossRef] [PubMed]

22. Anderson, S.C.; Handy, S.T. One-pot double Suzuki couplings of dichloropyrimidines. Synthesis 2010, 2721-2724.

23. Delia, T.J.; Schomaker, J.M.; Kalinda, A.S. The synthesis of substituted phenylpyrimidines via Suzuki coupling reactions. J. Heterocycl. Chem. 2006, 43, 127-131. [CrossRef]

24. Achelle, S.; Ramondenc, Y.; Marsais, F.; Plé, N. Star- and banana-shaped oligomers with a pyrimidine core: synthesis and light-emitting properties. Eur. J. Org. Chem. 2008, 3129-3140. [CrossRef]

25. Littke, A.F.; Fu, G.C. Palladium-catalyzed coupling reactions of aryl chlorides. Angew. Chem. Int. Ed. 2002, 41, 4176-7211. [CrossRef]

26. Lartia, R.; Allain, C.; Bordeau, G.; Schmidt, F.; Fiorini-Debuisschert, C.; Charra, F.; Teulade-Fichou, M.-P. Synthetic strategies to derivatizable triphenylamine displaying high two-photon absorption. J. Org. Chem. 2008, 73, 1732-1744. [CrossRef]

27. Katan, C.; Charlot, M.; Mongin, O.; Le Droumaguet, C.; Jouikov, V.; Terenziani, F.; Badaeva, E.; Tretiak, S.; Blanchard-Desce, M. Simultaneous control of emission localization and two-photon absorption efficiency in dissymmetrical chromophores. J. Phys. Chem. B 2010, 114, 3152-3169. [CrossRef]

28. Merkt, F.K.; Höwedes, S.P.; Gers-Panther, C.F.; Gruber, I.; Janiak, C.; Müller, T.J.J. Three-component activation/alkynylation/cyclocondensation (AACC) synthesis of enhanced emission solvatochromic 3-ethynylquinoxalines. Chem. Eur. J. 2018, 24, 8114-8125. [CrossRef]

29. Panthi, K.; Adhikari, R.M.; Kinstle, T.H. Aromatic fumaronitrile core-based donor-linker-acceptorlinker-donor (D-pi-A-pi-D) compounds: synthesis and photophysical properties. J. Phys. Chem. A 2010, 114, 4542-4549. [CrossRef]

30. Itami, K.; Yamazaki, D.; Yoshida, J.-I. Pyrimidine-core extended $\pi$-systems: general synthesis and interesting fluorescent properties. J. Am. Chem. Soc. 2004, 126, 15396-15397. [CrossRef]

31. Muraoka, H.; Obara, T.; Ogawa, S. Systematic synthesis, comparative studies of the optical properties, and the ICT-based sensor properties of a series of 2,4,6-tri(5-aryl-2-thienyl)pyrimidines with the D- $\pi$-A system. Tetrahedron Lett. 2016, 57, 3011-3015. [CrossRef] 
32. Fecková, M.; le Poul, P.; Robin-le Guen, F.; Roisnel, T.; Pytela, O.; Klikar, M.; Bureš, F.; Achelle, S. 2,4-Distyryland 2,4,6-tristyrylpyrimidines: synthesis and photophysical properties. J. Org. Chem. 2018, 83, 11712-11726. [CrossRef] [PubMed]

33. Rodríguez-Aguilar, J.; Vidal, M.; Pastenes, C.; Aliaga, C.; Caroli Rezende, M.; Domínguez, M. The solvatofluorochromism of 2,4,6-triarylpyrimidine derivatives. Photochem. Photobiol. 2018, 94, 1100-1108. [CrossRef] [PubMed]

34. Achelle, S.; Rodríguez-López, J.; Katan, C.; Robin-le Guen, F. Luminescence behavior of protonated methoxy-substituted diazine derivatives: toward white light emission. J. Phys. Chem. C 2016, 120, 26986-26995. [CrossRef]

35. Achelle, S.; Rodríguez-López, J.; Cabon, N.; Robin-le Guen, F. Protonable pyrimidine derivative for white light emission. RSC Adv. 2015, 5, 107396-107399. [CrossRef]

36. Telore, R.D.; Satam, M.A.; Sekar, N. Push-pull fluorophores with viscosity dependent and aggregation induced emissions insensitive to polarity. Dyes Pigm. 2015, 122, 359-367. [CrossRef]

37. Cvejn, D.; Michael, E.; Polyzos, I.; Almonasy, N.; Pytela, O.; Klikar, M.; Mikysek, T.; Giannetas, V.; Fakis, M.; Bureš, F. Modulation of (non)linear optical properties in tripodal molecules by variation of the peripheral cyano acceptor moieties and the $\pi$-spacer. J. Mater. Chem. C 2015, 3, 7345-7355. [CrossRef]

38. Le Droumaguet, C.; Sourdon, A.; Genin, E.; Mongin, O. Blanchard-Desce Two-photon polarity probes from octupolar fluorophores: synthesis, structure-properties relationships, and use in cellular imaging. Chem. Asian J. 2013, 8, 2984-3001. [CrossRef]

39. Dumat, B.; Bordeau, G.; Faurel-Paul, E.; Mahuteau-Betzer, F.; Saetel, N.; Metge, G.; Fiorini-Debuisschert, C.; Charra, F.; Teulade-Fichou, M.-P. DNA switches on the two-photon efficiency of an ultrabright triphenylamine fluorescent probe specific of AT regions. J. Am. Chem. Soc. 2013, 135, 12697-12706. [CrossRef]

40. Kwon, O.; Barlow, S.; Odom, S.A.; Beverina, L.; Thompson, N.J.; Zojer, E.; Brédas, J.-L.; Marder, S.R. Aromatic amines: a comparison of electron-donor strengths. J. Phys. Chem. A 2005, 109, 9346-9352. [CrossRef]

41. Tydlitát, J.; Achelle, S.; Rodríguez-López, J.; Pytela, O.; Mikýsek, T.; Cabon, N.; Robin-le Guen, F.; Miklík, D.; Růžičková, Z.; Bureš, F. Photophysical properties of acid-responsive triphenylamine derivatives bearing pyridine fragments: towards white light emission. Dyes Pigm. 2017, 146, 467-478. [CrossRef]

42. Parthasarathy, V.; Fery-Forgues, S.; Campioli, E.; Recher, G.; Terenziani, F.; Blanchard-Desce, M. Dipolar versus octupolar triphenylamine-based fluorescent organic nanoparticles as brillant one- and two-photon emitters for (bio)imaging. Small 2011, 7, 3219-3229. [CrossRef] [PubMed]

43. Zhu, H.; Huang, J.; Kong, L.; Tian, Y.; Yang, J. Branched triphenylamine luminophores: aggregation-induced fluorescence emission, and tunable near-infrared solid-state fluorescence characteristics via external mechanical stimuli. Dyes Pigm. 2018, 151, 140-149. [CrossRef]

44. Weng, J.; Mei, Q.; Fan, Q.; Ling, Q.; Tong, B.; Huang, W. Bipolar luminescent materials containing pyrimidine terminals: synthesis, photophysical properties and a theoretical study. RSC Adv. 2013, 3, 21877-21887. [CrossRef]

45. Kato, S.-I.; Yamada, Y.; Hiyoshi, H.; Umezu, K.; Nakamura, Y. Series of carbazole-pyrimidine conjugates: syntheses and electronic, photophysical, and electrochemical properties. J. Org. Chem. 2015, 80, 9076-9090. [CrossRef] [PubMed]

46. Reichardt, C. Solvatochromic dyes as solvent polarity indicators. Chem. Rev. 1994, 94, 2319-2358. [CrossRef]

47. Cerón-Carrasco, J.P.; Jacquemin, D.; Laurence, C.; Planchat, A.; Reichardt, C.; Sraïdi, K. Solvent polarity scales: determination of new Et(30) values for 84 organic solvents. J. Phys. Org. Chem. 2014, 27, 512-518. [CrossRef]

48. Achelle, S.; Nouira, I.; Pfaffinger, B.; Ramondenc, Y.; Plé, N.; Rodríguez-López, J. V-shaped 4,6-bis(arylvinyl) pyrimidine oligomers: synthesis and optical properties. J. Org. Chem. 2009, 74, 3711-3717. [CrossRef]

49. Liu, D.; Zhang, Z.; Zhang, H.; Wang, Y. A novel approach towards white photoluminescence and electrolum inescence by controlled protonation of a blue fluorophore. Chem. Commun. 2013, 49, 10001-10003. [CrossRef]

50. Liu, C.; Wu, Y.; Qiu, J. Efficient synthesis of 4-heteroaryl-substituted triphenylamine derivatives via a ligand-free Suzuki reaction. Appl. Organomet. Chem. 2011, 25, 862-866. [CrossRef]

Sample Availability: Samples of the compounds 1 and $\mathbf{2}$ are available from the authors. 